\title{
NEW MEXICANS' PERCEPTIONS OF LOS ALAMOS National LABORATORY: AWARENESS AND EVALUATIONS
}

\author{
PREPARED FOR: \\ PUBLIC AFFAIRS DIVISION \\ LOS ALAMOS NATIONAL LABORATORY \\ LOS ALAMOS, NEW MEXICO
}

PREPARED BY:
UNM INSTITUTE FOR PUBLIC POLICY
UNIVERSITY OF NEW MEXICO
ALBUQUERQUE, NEW MEXICO

\section{DISCLAIMER}

This report was prepared as an account of work sponsored by an agency of the United States Government. Neither the United States Government nor any agency thereof, nor any of their employees, makes any warranty, express or implied, or assumes any legal liability or responsibility for the accuracy, completeness, or usefulness of any information, apparatus, product, or * process disclosed, or represents that its use would not infringe privately owned rights. Reference herein to any specific commercial product, process, or service by trade name, trademark, manufacturer, or otherwise does not necessarily constitute or imply its endorsement, recommendation, or favoring by the United States Government or any agency thereof. The views and opinions of authors expressed herein do not necessarily state or reflect those of the United States Government or any agency thereof. 


\section{DISCLAIMER}

\section{Portions of this document may be illegible in electronic image products. Images are produced from the best available original document.}




\section{EXECUTIVE SUMMARY}

- Seventy-eight percent of the New Mexicans surveyed hold a generally favorable view of LANL, while about 11 percent hold less favorable views. About 11 percent of the respondents gave no answer or said they don't know.

- Respondents from the six counties surrounding the Laboratory were more likely to indicate a favorable view of LANL ( 84 percent) than were residents of any other geographic region. About 72 percent of Santa Fe County residents held a favorable view of LANL.

- Respondents who said they are proud the Laboratory is in New Mexico are more favorable toward LANL, as are respondents who said they had read a newspaper article about LANL in the past six months.

- Twenty two percent of the respondents said LANL is very environmentally responsible, while four percent said it is not at all responsible.

- Men tend to view the Laboratory as less environmentally responsible than do women. Self-identified conservatives indicated LANL is more environmentally responsible than did less conservative residents.

- More Los Alamos County residents (58 percent) are in favor of decreasing efforts on defense and weapons development than are in favor of increasing such efforts ( 33 percent). New Mexicans in general, however, are more in favor of increasing such efforts, at 51 percent.

- In general, research scientists received the highest average trust rating, at 6.9 on a ten-point scale, where ten is completely trustworthy. A savings and loan spokesperson was the least trusted by our respondents, with a 3.7 on the ten-point scale. A Los Alamos National Laboratory spokesperson was the second most trusted, at 6.2 . 
Introduction

This report uses survey data to profile New Mexico residents' perceptions of Los Alamos National Laboratory (LANL). The survey results are the responses of a representative, randomly selected sample of New Mexico households to set of questions asked in September and October 1990. The data allow statistical inference to the general population's responses to the same set of questions at the time the survey was administered. The results provide an overview of New Mexico residents' current perceptions of LANL. The sample margin of error is slightly less than plus or minus five percent.

Because our sample frame is designed to be proportionate to population, counties with the smallest populations, such as Mora and Los Alamos, tend to have very few respondents in a standard sample. In order to have sample sizes sufficiently large to discern statistically significant differences across these counties, we took additional, non-proportionate random samples from Los Alamos County and its neighboring counties, including Rio Arriba, Taos, San Miguel, Mora and Sandoval Counties. This required the specification of new sample frames for each of the six counties and an additional sample of 300 respondents (50 in each county). Therefore, the analysis for this report is somewhat more complex than usual in that two separate samples will be analyzed - the state-wide random sample and the oversample.

As part of this analysis, we defined several geographic regions of the state in order to gain a better understanding of the effect of regional variation on perceptions of LANL. The geographic breakdown developed for LANL uses four distinct regions for analysis. These are defined as follows:

The State as a Whole -- includes the entire state:

The Six County Reglon (SCR) -- includes the six counties immediately surrounding LANL: Rio Arriba, Taos, Mora, San Miguel, Sandoval and Los Alamos.

Santa Fe County -- Excluded from the counties surrounding Los Alamos National Lab because of its significant difference from the other six counties.

The Rest of the State (RONM) -- includes all areas of the state except the Six County Region and Santa Fe County. 
Some survey questions also were asked of respondents to our Quarterly Profile of New Mexico Citizens in May and August, 1990. Where appropriate, comparisons from this survey were made with responses to the same questions in the May and August Profile surveys.

\section{PERCEPTION OF TYPES OF RESEARCH IN WHICH LANL IS ENGAGED}

Respondents were asked to identify the types of research in which they believe the Laboratory is engaged. These responses were then organized into six main categories: Pure science/research, medical research, environmental research, defense/weapons development, technology transfer to industry, and other. Because respondents could provide more than one answer to this question, total percentages may be greater than 100 .

The most frequent response, about 37 percent, was that LANL is engaged in defense/weapons development. Pure science/research was identified by 19 percent, 10 percent said medical research, three percent said environmental research and one percent said technology transfer. Thirty percent identified "other" categories of research.

Residents of the SCR differed only slightly in their responses to this question. Fortyfour percent said the Laboratory is involved in defense/weapons development, 14 percent said pure science/research, 12 percent said medical research, six percent said environmental research, three percent said technology transfer to industry, and 26 percent said other research.

About 45 percent of Santa Fe County respondents said the Laboratory is involved in defense-related research, 20 percent said medical research, six percent said pure science, four percent said environmental research, two percent said technology transfer, and 37 percent identified other research.

genERAL PERCEPTIONS OF LOS ALAMOS NATIONAL LABORATORY 
As indicated in Figure One, more than 38 percent of the respondents said their view of Los Alamos National Laboratory is very favorable, while nearly 40 percent said it is somewhat favorable. About 11 percent of the respondents said their view of the Laboratory is somewhat or very unfavorable. Eleven percent answered "don't know" to this question.

In an August, 1990 survey asking the same questions, about 33 percent said their view of LANL is very favorable and 39 percent said their view is somewhat favorable. Eleven percent of the August respondents indicated their view is somewhat unfavorable or very unfavorable, while 17 percent said they don't know.

\section{FIGURE ONE}

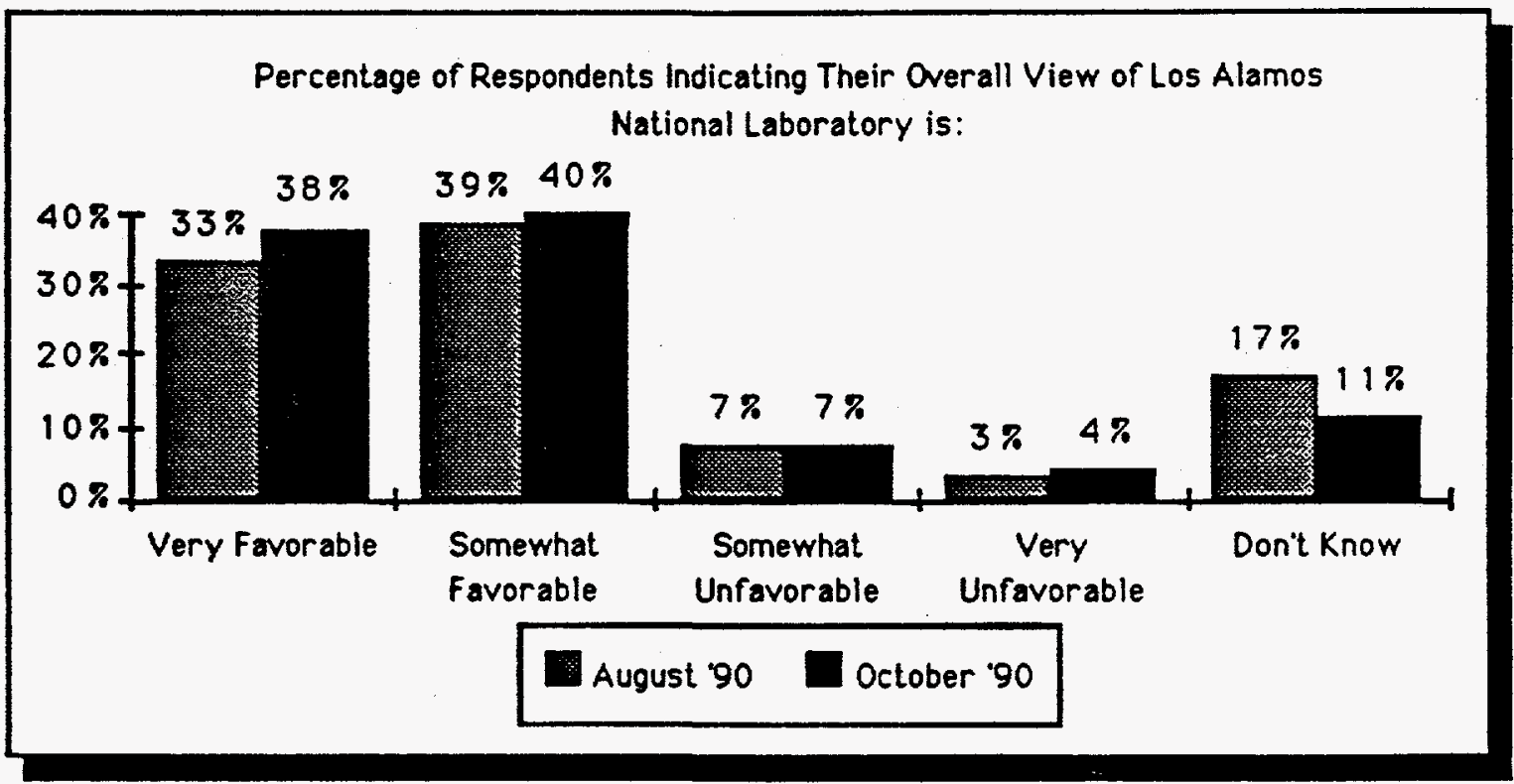

Looking specifically at the six counties surrounding LANL and Santa Fe County, 84 percent of the SCR residents said their view is somewhat favorable or very favorable. About 72 percent of Santa Fe residents said their view of LANL is favorable.

These numbers differ little from the responses to the August survey, in which 82 percent of the SCR residents indicated a favorable view and 69 percent of Santa Fe County residents said their view of the Lab is favorable. Figure two provides the breakdown of responses to this question in the August and October surveys. 


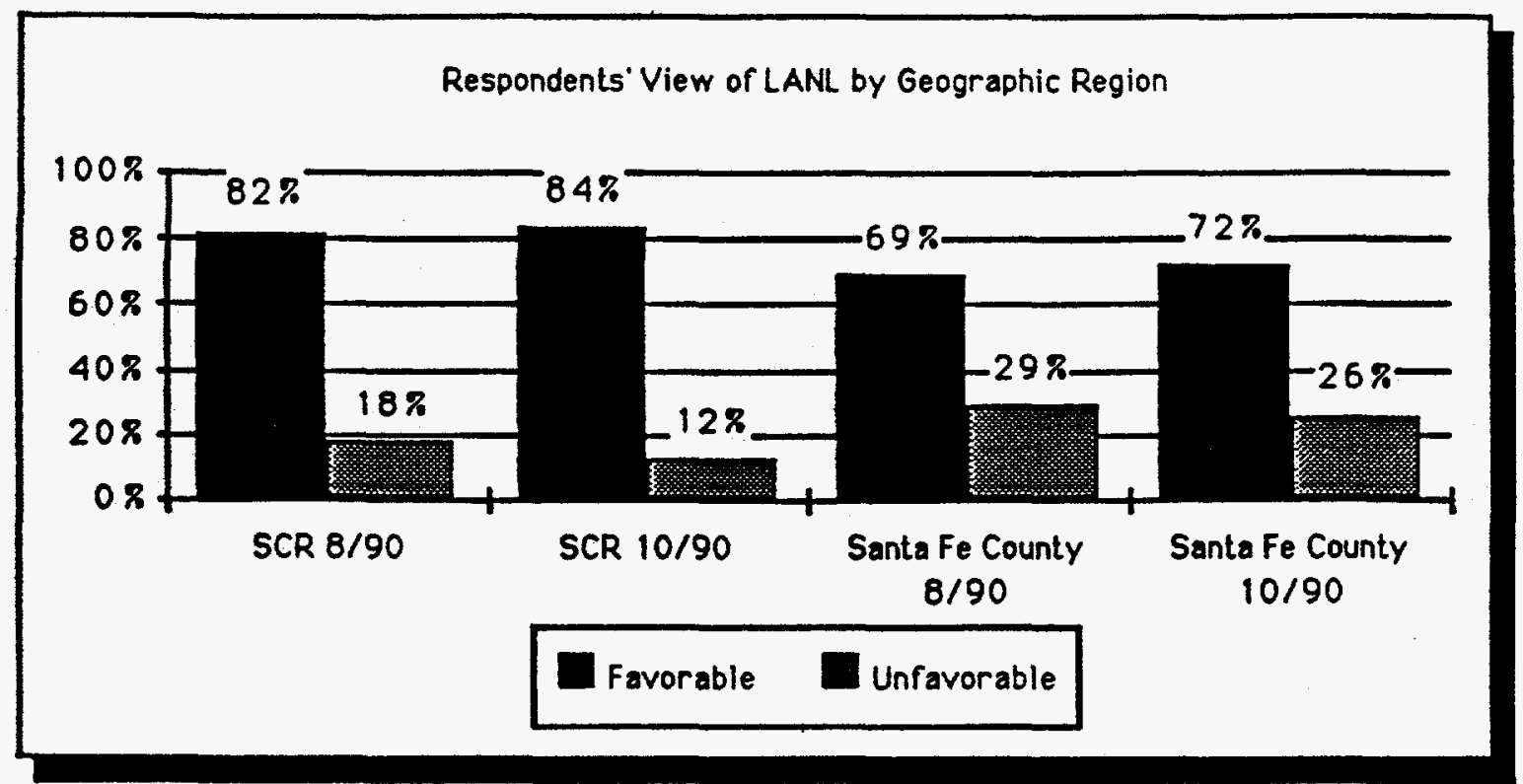

Responses to this question also were analyzed for each county in the SCR and Santa Fe County. Table One provides the responses to this question for each county, the SCR and the entire state.

Institute for Public Policy 


\section{Iable One}

$\begin{array}{llll}\text { Beoion } & \text { Eavorable } & \text { Unfavorable } & \text { Don't Know } \\ \text { New Mexico } & 78 \% & 11 \% & 11 \% \\ \text { SCR* } & 84 \% & 12 \% & 4 \% \\ \text { Los Alamos } & 94 \% & 5 \% & 2 \% \\ \text { Santa Fe } & 72 \% & 26 \% & 6 \% \\ \text { Rio Arriba } & 82 \% & 12 \% & 2 \% \\ \text { San Miguel } & 88 \% & 7 \% & 5 \% \\ \text { Mora } & 86 \% & 4 \% & 10 \% \\ \text { Taos } & 76 \% & 24 \% & 0 \% \\ \text { Sandoval } & 79 \% & 19 \% & 2 \%\end{array}$

- Using an analysis of variance statistical technique, SCR responses are significantly different from those of the entire state.

As indicated in Table One, more Los Alamos County residents expressed a favorable view of LANL than did residents of any other county. With the exceptions of Santa Fe and Taos County, residents of these Northern counties have a more favorable view of LANL than do residents of New Mexico in general.

For all New Mexico respondents, an ordinary least squares regression technique identified four factors that appear to influence a respondent's overall view of LANL. Respondents who indicated greater trust in a LANL spokesperson and who disagreed with the statement that science can be interpreted to fit any point of view were more likely to view the Laboratory favorably. Other key factors were respondents who said the Laboratory is something the state can be proud of, and who have read a newspaper article about LANL in the past six months were more likely to view the Laboratory more favorably than were other respondents. Please refer to Table 13 in Appendix A for complete regression coefficients and probabilities.

For the SCR, three factors provide clues to respondents' overall view of LoS Alamos National Laboratory. Women generally view the lab less favorably than do men, while respondents who indicated they have read a newspaper article about the Laboratory in the last six months are more favorable toward the Lab. Respondents who agreed with the statement that the Laboratory is something the state of New Mexico can be proud of also are more favorable of 
LANL. Table 14 in Appendix A provides complete regression coefficients and probabilities for the SCR.

\section{PERCEPTION OF LANL'S ENVIRONMENTAL RESPONSIBILITY}

Respondents were asked to indicate their view of LANL's environmental responsibility on a five point scale, with one indicating the Laboratory is environmentally irresponsible and five being LANL is very responsible. Overall, about 22 percent indicated Los Alamos is very environmentally responsible and four percent said LANL is irresponsible. Some 15 percent gave no response to this question or said they did not know.

These results, along with responses to the same question asked in May, 1990, and August, 1990, are provided in Figure Three.

\section{FIGURE THREE}

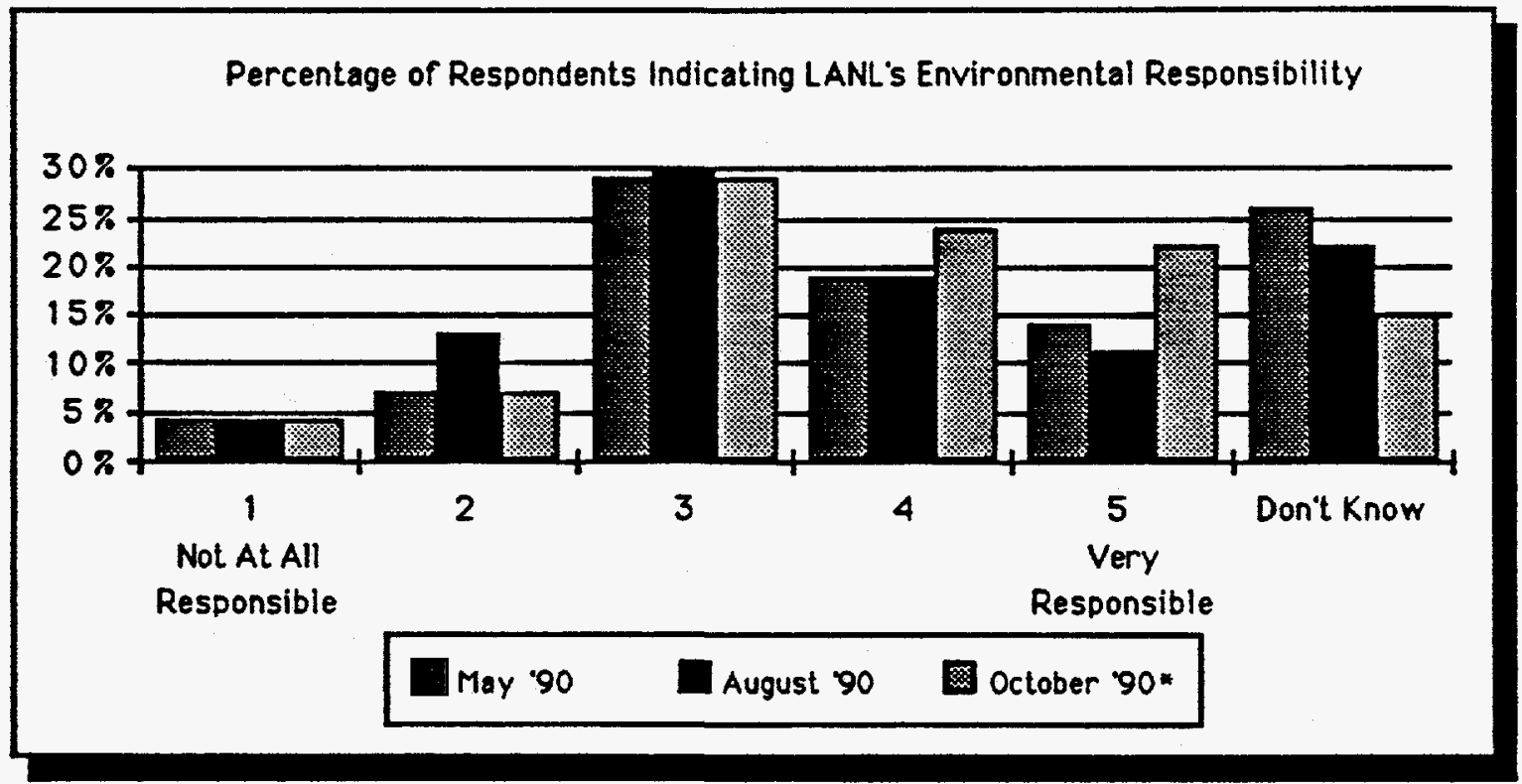

* Question wording differed slightly for the October survey. The scale for this survey ran from very irresponsible to very responsible, while the scale for the May and August surveys was not at all responsible to very responsible.

Few differences can be seen among the responses to the three surveys, except fewer people answered "don't know" to this question in the most recent survey and a greater proportion said the Laboratory is environmentally responsible.

For the state as a whole, an ordinary least squares regression analysis indicated that four variables significantly affected a respondent's view of LANL's environmental 
responsibility. Respondents who indicated a greater trust in a LANL spokesperson view the Laboratory as more responsible, while women and self-identified conservatives also view the Laboratory as more environmentally responsible. One other significant difference was that respondents who agreed that technology has become dangerous and unmanageable tend to view the Lab as less environmentally responsible than do respondents who disagreed with that statement. Please refer to Table 15 in Appendix A for regression coefficients and probabilities.

Looking strictly at demographic variables, only ideology and education are statistically significant. Respondents with less education tend to view the Laboratory as more environmentally responsible than do better educated residents, and conservative respondents view LANL as more responsible than do liberal respondents. However, it is important to remember that when other variables. such as trust in a LANL spokesperson, are included in this regression, these two variables no longer are statistically significant. Table 15.1 in Appendix A provides the regression coefficients and probabilities values for this analysis.

For the SCR, only three variables significantly affect a respondent's view of the Laboratory's environmental responsibility. The longer a respondent has lived in New Mexico, the more environmentally responsible the Laboratory is viewed. Also, the respondent's attitude toward science was important: those who agree with the statements that science tells us the truth about the world and that science only can be understood by scientists view LANL as more environmentally responsible. For complete regression coefficients and probabilities for this question, please refer to Table 16 in Appendix A.

\section{THE LABORATORY'S EFFECT ON THE NEW MEXICO ECONOMY}

Respondents were asked to indicate the effect they believe the Laboratory has on the New Mexico economy, with response categories ranging from "very harmful" to "very beneficial." About 44 percent of the respondents said the Laboratory is very beneficial and one percent said it is very harmful. As Figure Four indicates, the majority of responses were clustered in the upper half of the scale. 


\section{FIGURE FOUR}

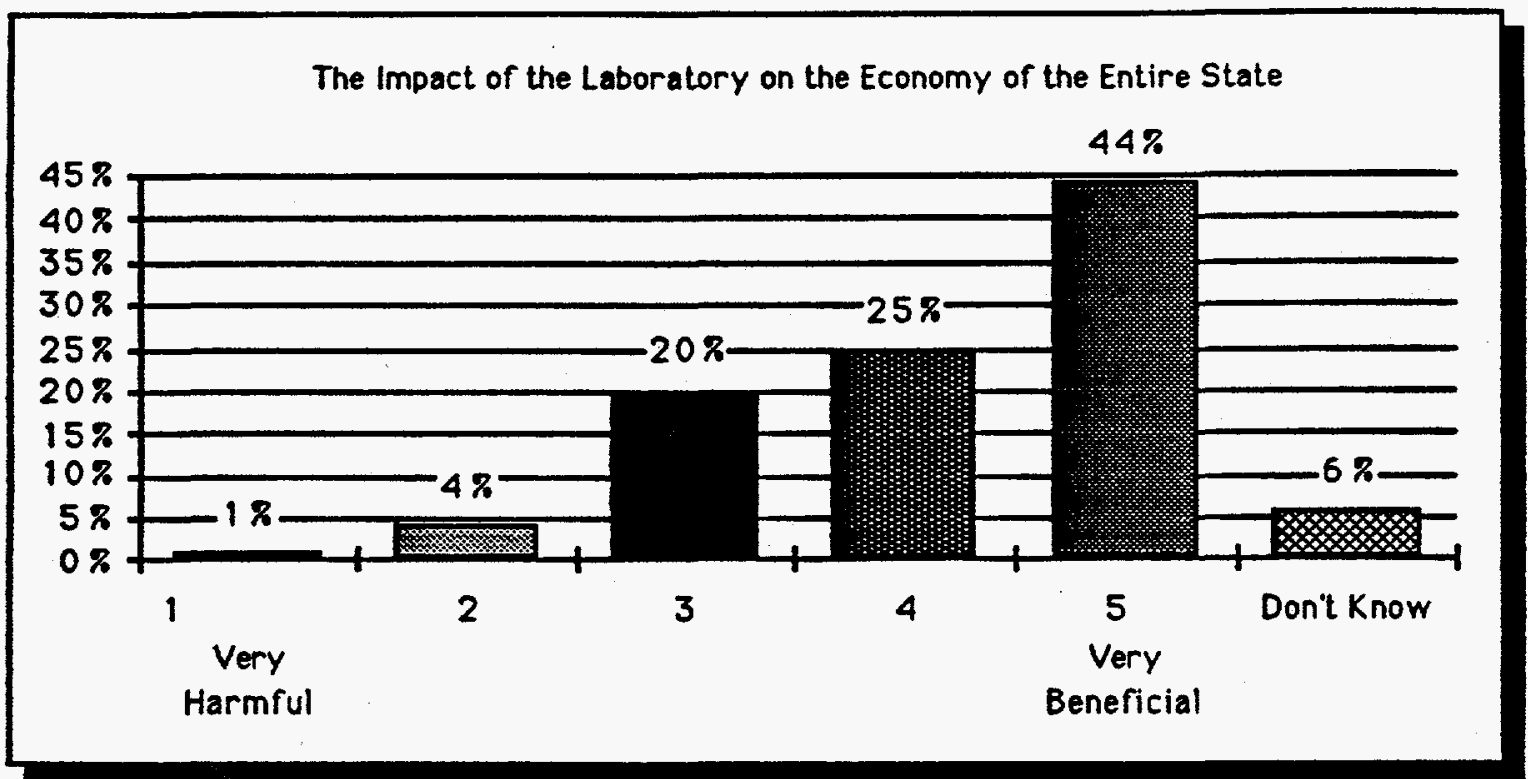

When the analysis is limited to the SCR, an even larger fraction of the residents view the Laboratory as beneficial to the economy. About 53 percent of those respondents view Los Alamos as very beneficial, and only two percent believe it is very harmful. Figure Five provides the complete breakdown of responses for the SCR to this question.

\section{FIGURE FIVE}

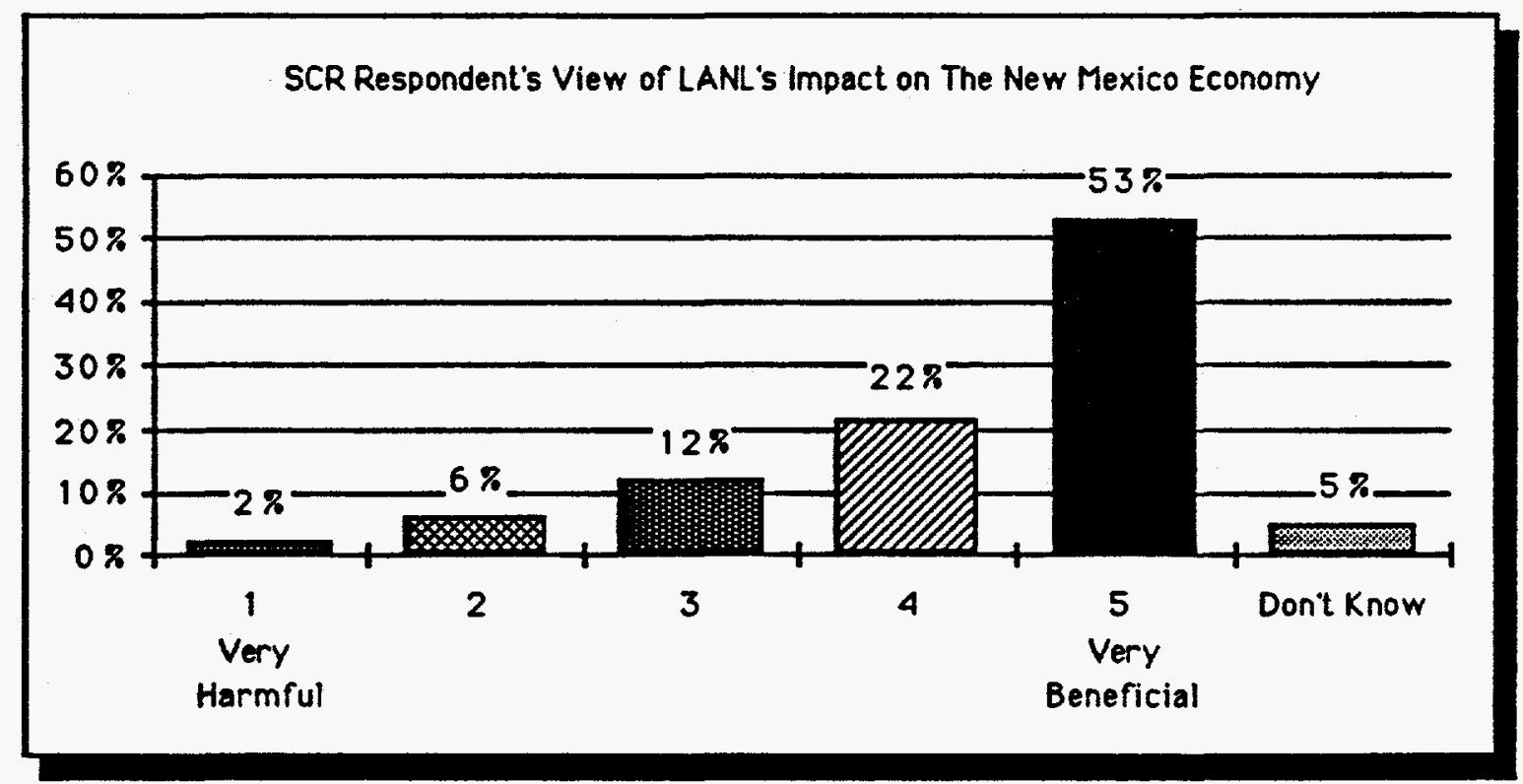

Institute for Public Policy 
Santa $\mathrm{Fe}$ County responses were almost identical to those of the SCR, as Figure Six indicates. Some 53 percent of Santa Fe respondents indicated LANL is very beneficial to the New Mexico economy, while two percent said it is very harmful.

\section{FIGURE SIX}

Santa Fe County's View of the Impact of the Laboratory on the Economy of the Entire State

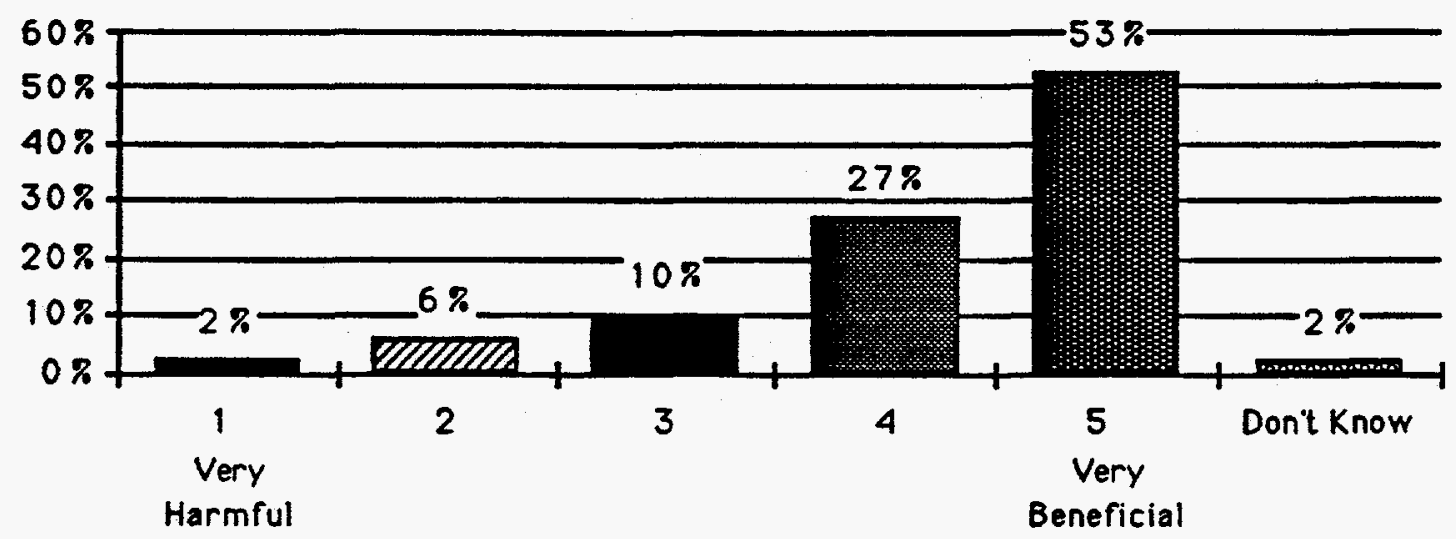

\section{LANL'S EFFECT ON THE NORTHERN NEW MEXICO ECONOMY}

Respondents from the SCR and Santa Fe County were asked two additional questions regarding the Laboratory's effect on the economy of Northern New Mexico.

On a five point scale, with one being very harmful and five being very beneficial, respondents from these counties were asked to indicate LANL's impact on the economy of Northern New Mexico. About 41 percent said the Laboratory's impact is very beneficial and three percent said it is very harmful. Figure Seven provides a complete breakdown of the responses to this question. 


\section{FIGURE SEVEN}

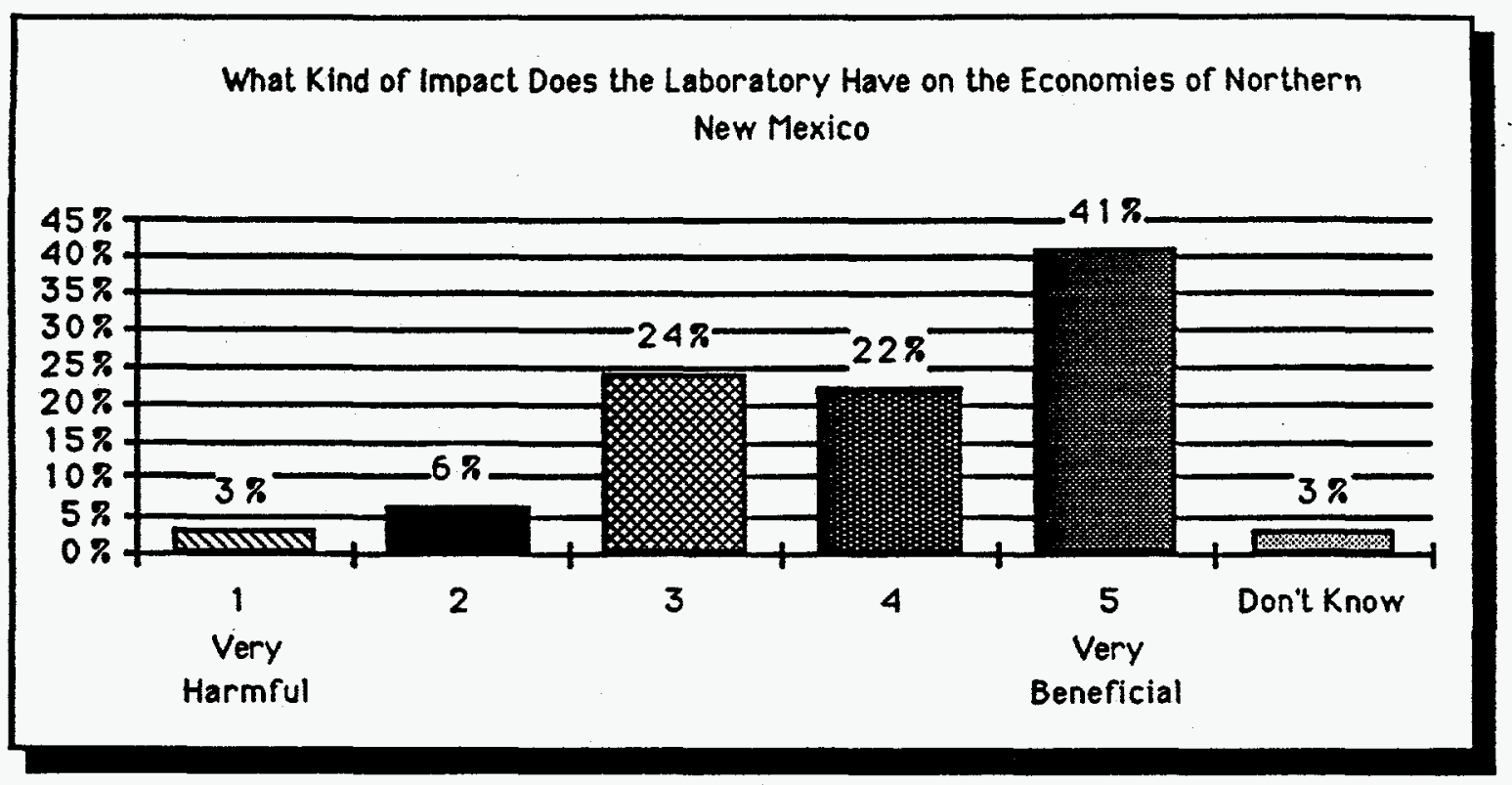

Respondents also were asked to indicate whether they agreed strongly, agreed, disagreed or disagreed strongly with the statement that the Northern New Mexico economies are too dependent on the Laboratory. As shown in Figure Eight, about 21 percent of the respondents said they agree strongly with the statement and 33 percent said they agree. About 36 percent disagreed with the statement and six percent disagreed strongly with the statement. 


\section{FIGURE EIGHT}

Northern New Mexico's Communities are too Dependent on the Laboratory's Contribution to the Local Economy

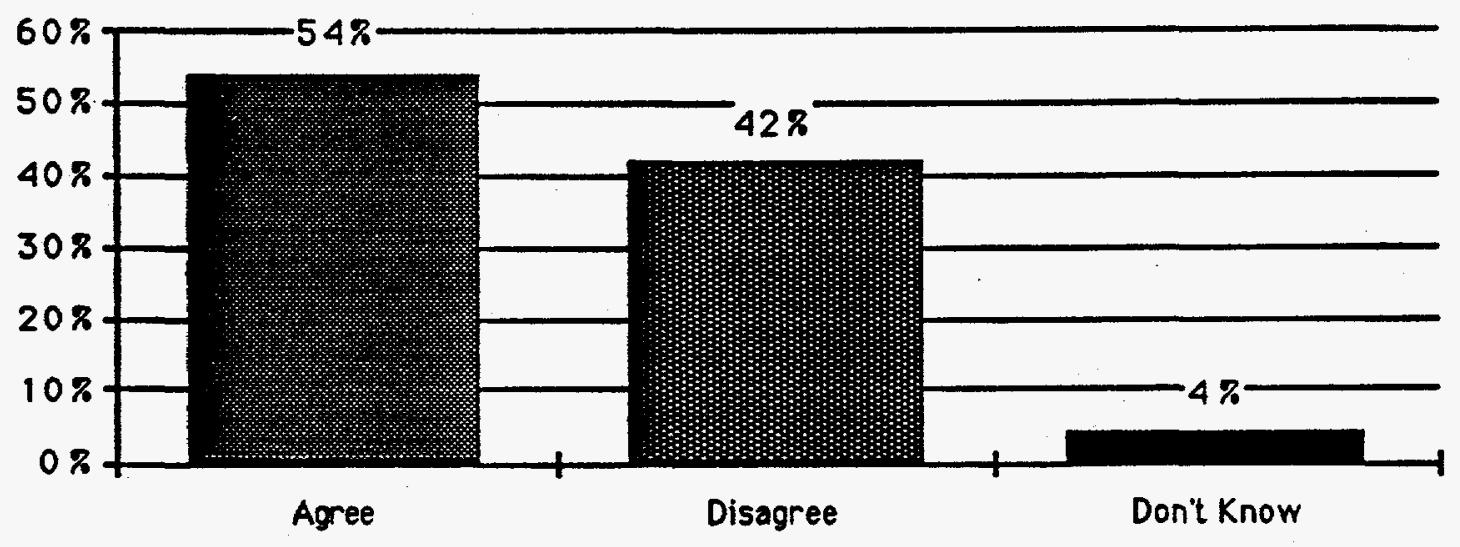

THE LABORATORY'S EFFECT ON NATIONAL DEFENSE

Figure Nine shows the responses of New Mexicans to the questions regarding LANL's effect on national defense. Fully 48 percent of the survey respondents said LANL's effect on national defense is very beneficial, while slightly less than two percent said it is very harmful. About seven percent of the respondents gave no answer or said they don't know. 
The Effect of the Laboratory in National Defense

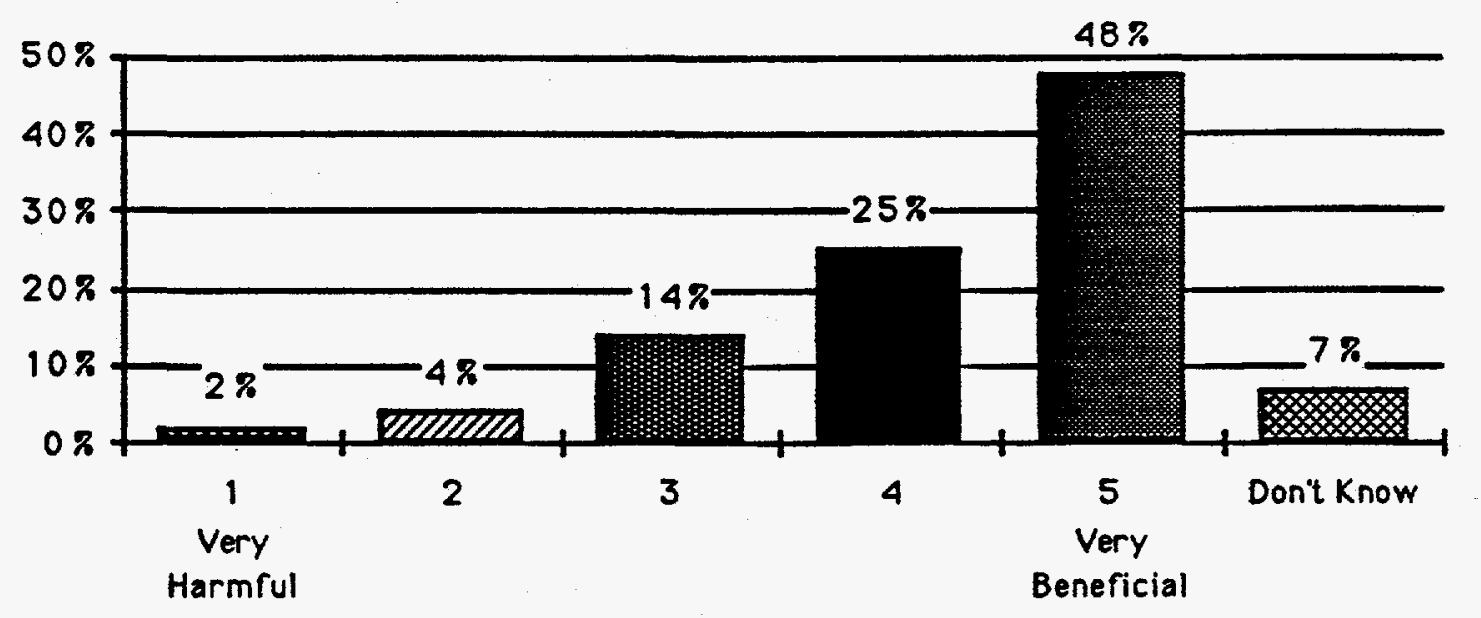

SCR respondents view the Laboratory as slightly more beneficial to national defense than did New Mexicans in general, with about 53 percent saying the Laboratory is very beneficial and only one percent indicating it is very harmful. About 49 percent of Santa Fe County residents indicated the Laboratory is very beneficial and four percent said it is very harmful.

FIGURE TEN

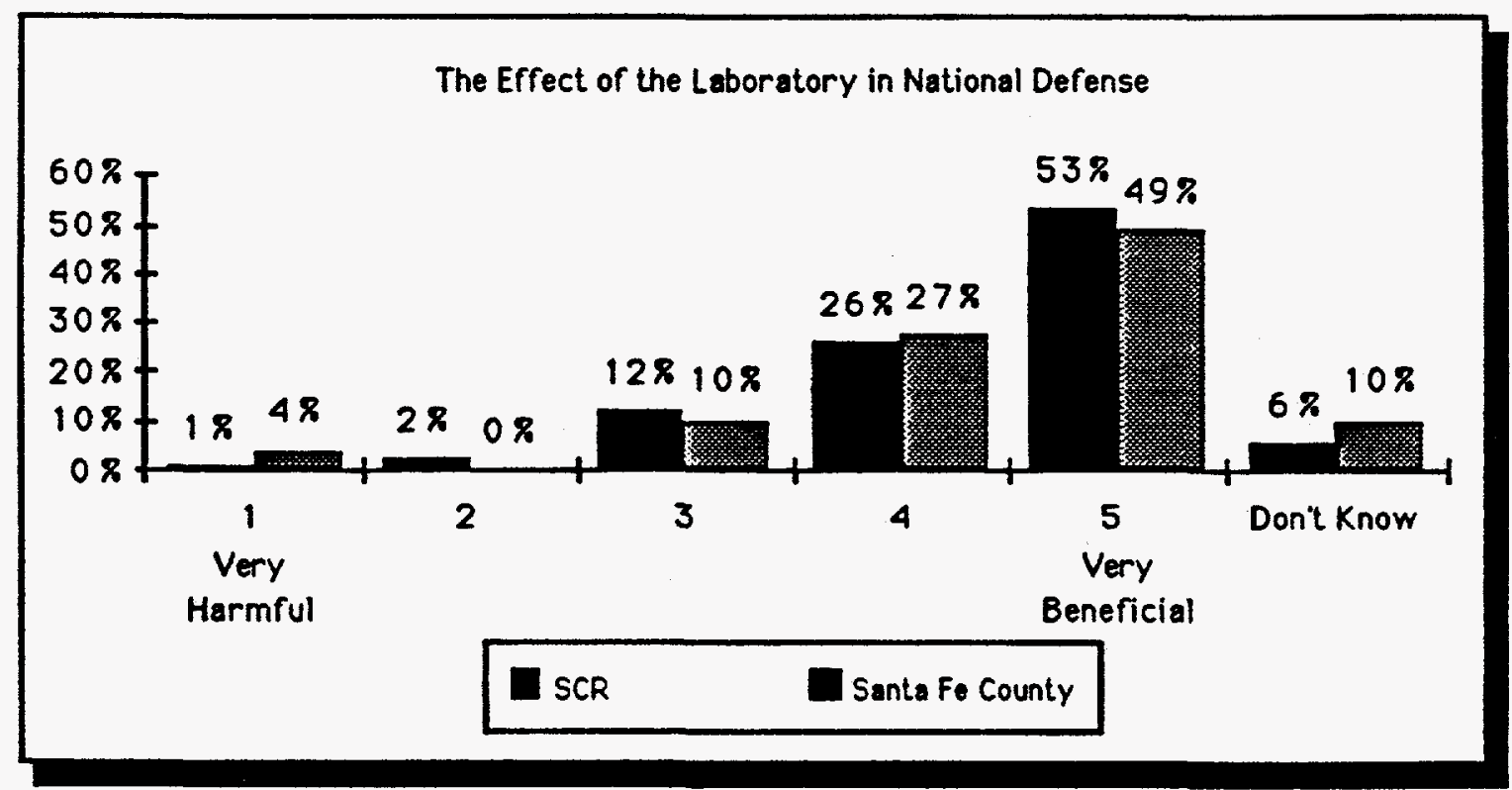


Two variables are significant indicators of a respondent's view of LANL's impact on national defense. Conservative respondents view the Laboratory as more beneficial than do liberal respondents. Those who agree with the statement that technology can solve society's problems view the Laboratory as more beneficial. Table 17 in Appendix A provides the complete regression coefficients and probabilities.

\section{PRIDE IN LOS ALAMOS NATIONAL LABORATORY}

For the entire state, more than 39 percent of the respondents agreed strongly with the statement, "Overall Los Alamos National Laboratory is something that the state of New Mexico can be proud of." About 52 percent of the respondents said they agreed with this statement, while 7 percent said they disagreed or disagreed strongly with it.

About 49 percent of the residents of the SCR agreed strongly with that statement and 41 percent said they agreed with the statement. Eight percent said they disagreed or disagreed strongly with the statement. Figure Eleven provides a breakdown of the responses to this question

\section{FIGURE ELEVEN}

Qverall, Los Alamos National Laboratory is something that the State of New Mexico Can be Proud of:

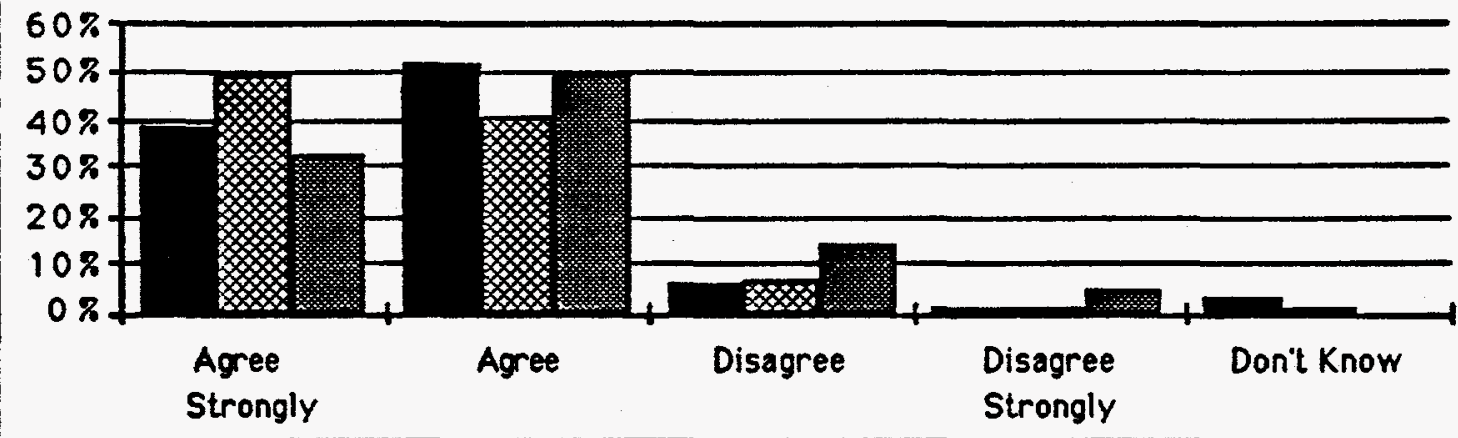

State

SCR

Santa Fe County

Table Two indicates that residents of Los Alamos County take more pride in the Laboratory -- fully 98 percent - than do residents of any other county. Although most Taos County residents indicated pride in the existence of the Laboratory in New Mexico, fewer agreed or agreed strongly with the statement than did residents of any other region. 
Iable Iwe

Pride in Los Alamos National Laboratory

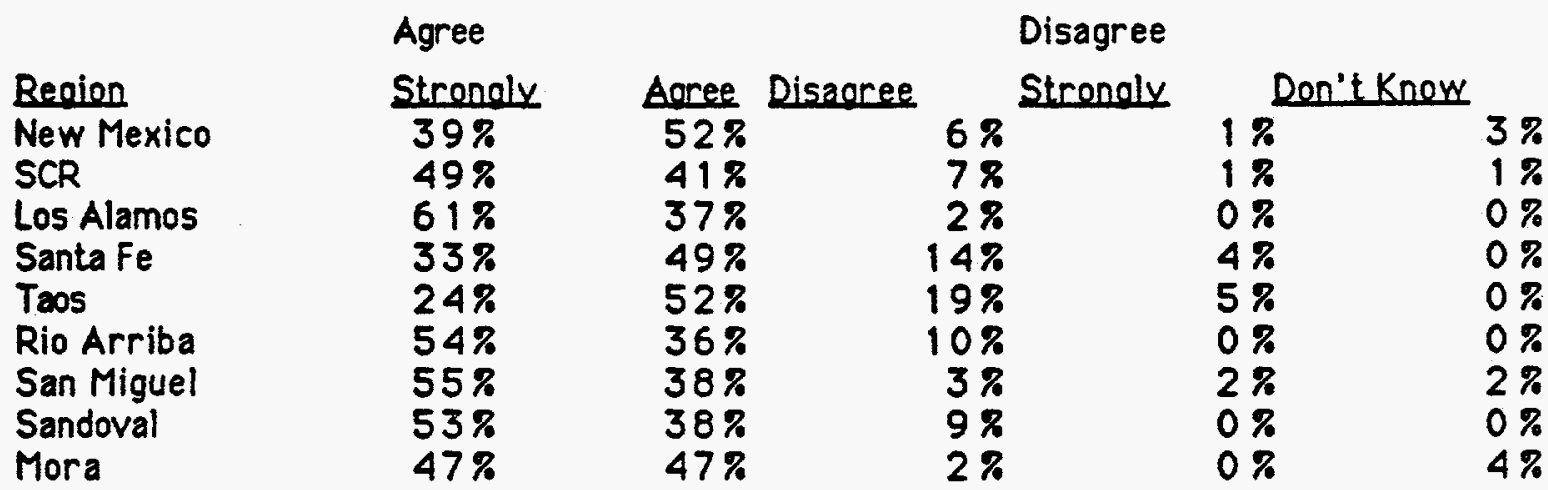

Using an ordinary least squares regression technique, three key ingredients appear to be significant indicators of a respondent's pride in having LANL in New Mexico. Respondents who place more trust in a LANL spokesperson, who have lived in New Mexico longer, and who have seen a television news story about the Laboratory in the past six months are significantly more proud of having LANL in the state than are other respondents. Table 18 in Appendix A provides the complete regression coefficients and probabilities for this analysis.

VIEW OF LANL AS A PLACE TO WORK

About 28 percent of the respondents from New Mexico indicated they work for the Laboratory or know someone who does. This number increased to 59 percent for the SCR and 67 percent for Santa Fe County.

of those indicating they work for LANL or who know someone who does, 39 percent said the Laboratory is an excellent place to work. 49 percent said it is a good place to work. 10 percent said it is fair and two percent rated it as poor. The percentages for the SCR were not significantly different, with 40 percent rating LANL as excellent, 46 percent rating it good, 12 percent said fair and 2 percent said poor. Figure Twelve shows the responses to this question for the entire state. 
Given What You Know About the Laboratory. How Would You Rate It as a Place

to Work

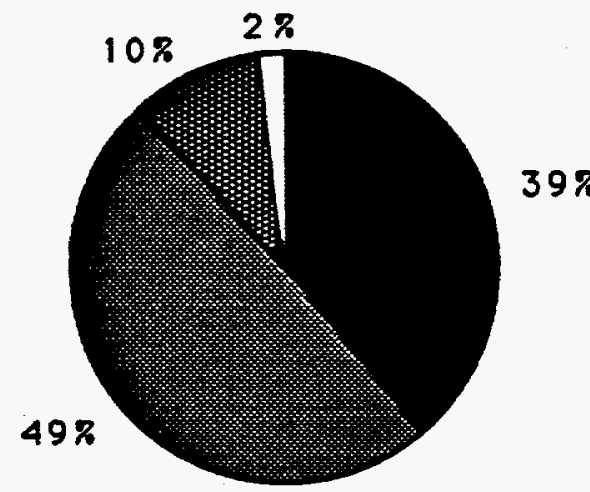

Excellent

Good

Fair

Poor

Forty-five percent of Santa Fe respondents said the Laboratory is an excellent employer, 42 percent said good, 10 percent said fair and three percent said poor.

IMPACT OF LANL ON RESPONDENTS' FAMILIES

Overall, respondents were fairly evenly split on the question of the Laboratory's impact on their families. About 21 percent chose point one or two on the five-point scale, indicating LANL is harmful to their families. About 28 percent chose points four and five on the scale, indicating the Laboratory is beneficial, while 33 percent chose the mid-point on the scale and 17 percent said they don't know. Figure 13 provides the percentages for this question for the entire state. 


\section{FIGURE THIRTEEN}

The Impact of Los Alamos National Laboratory on You and Your Family

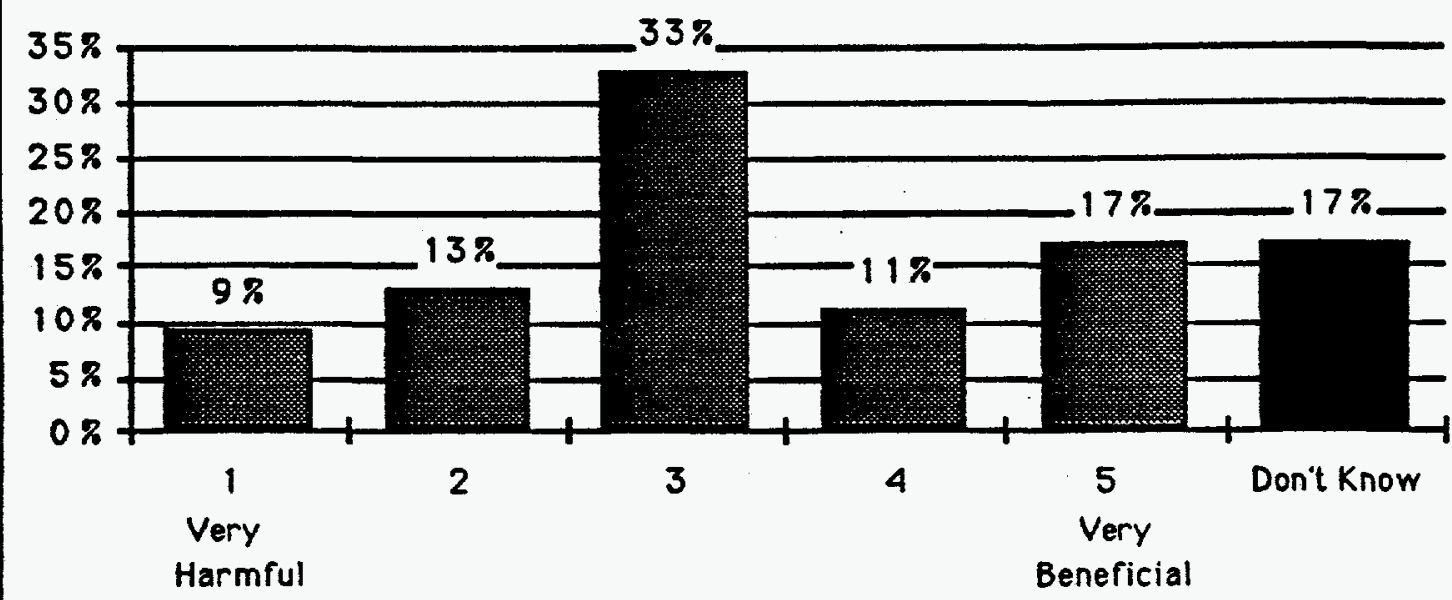

More SCR respondents view the Laboratory as beneficial than do residents of the state in general, with 46 percent choosing points four or five on the scale. Only about 19 percent said LANL is harmful to their families and 28 percent chose the midpoint on the scale. Seven percent answered "don't know" to this question. Figure 14 provides the complete breakdown of responses for SCR residents to this question.

\section{FIGURE FOURTEEN}

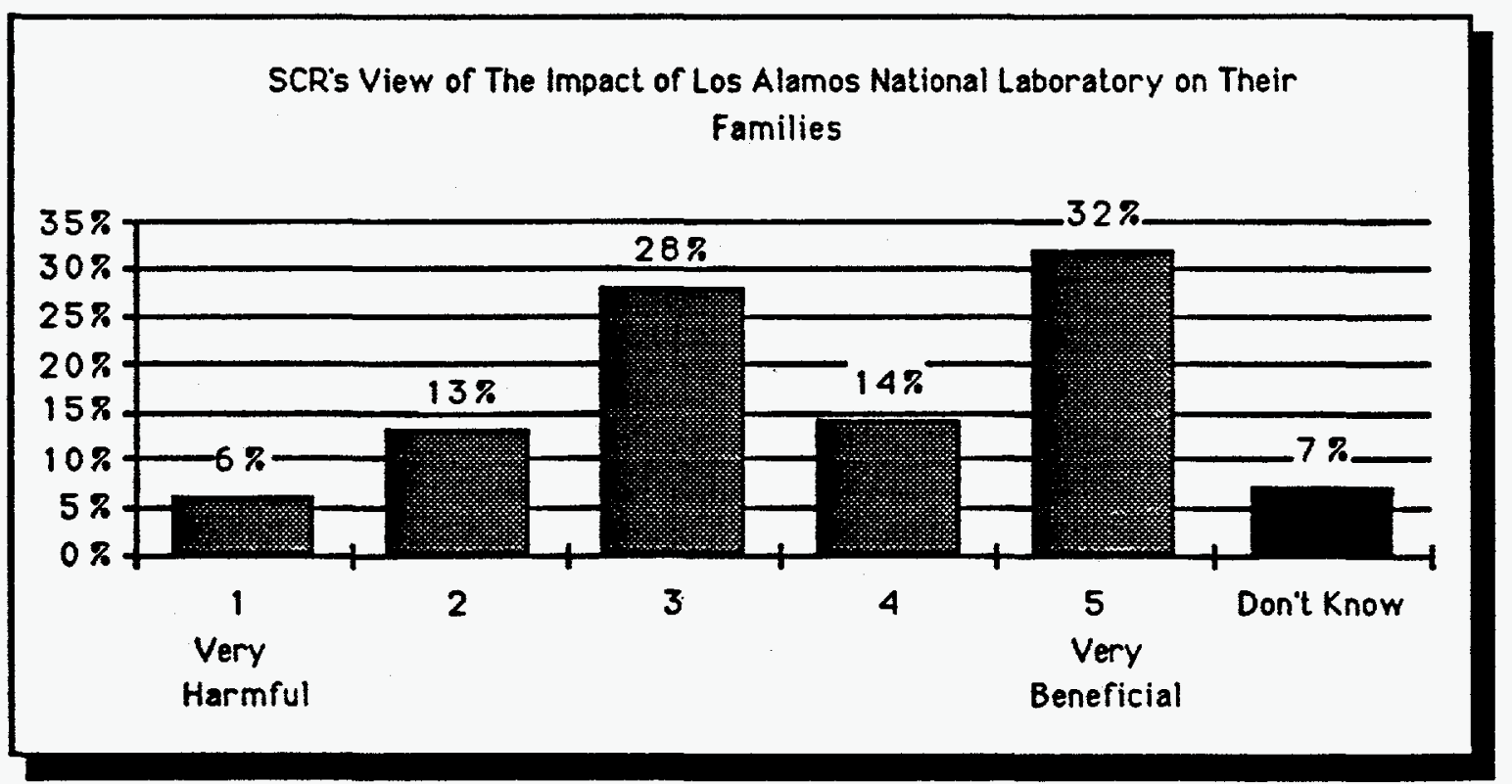


Santa Fe residents provided almost identical responses to this question as did SCR respondents. Some 24 percent said the Laboratory is harmful, with 14 percent indicating it is very harmful. About 27 percent chose the midpoint on the scale, 41 percent said LANL is beneficial and eight percent said they don't know. Figure 15 provides the percentage responses to this question.

\section{FIGURE FIFTEEN}

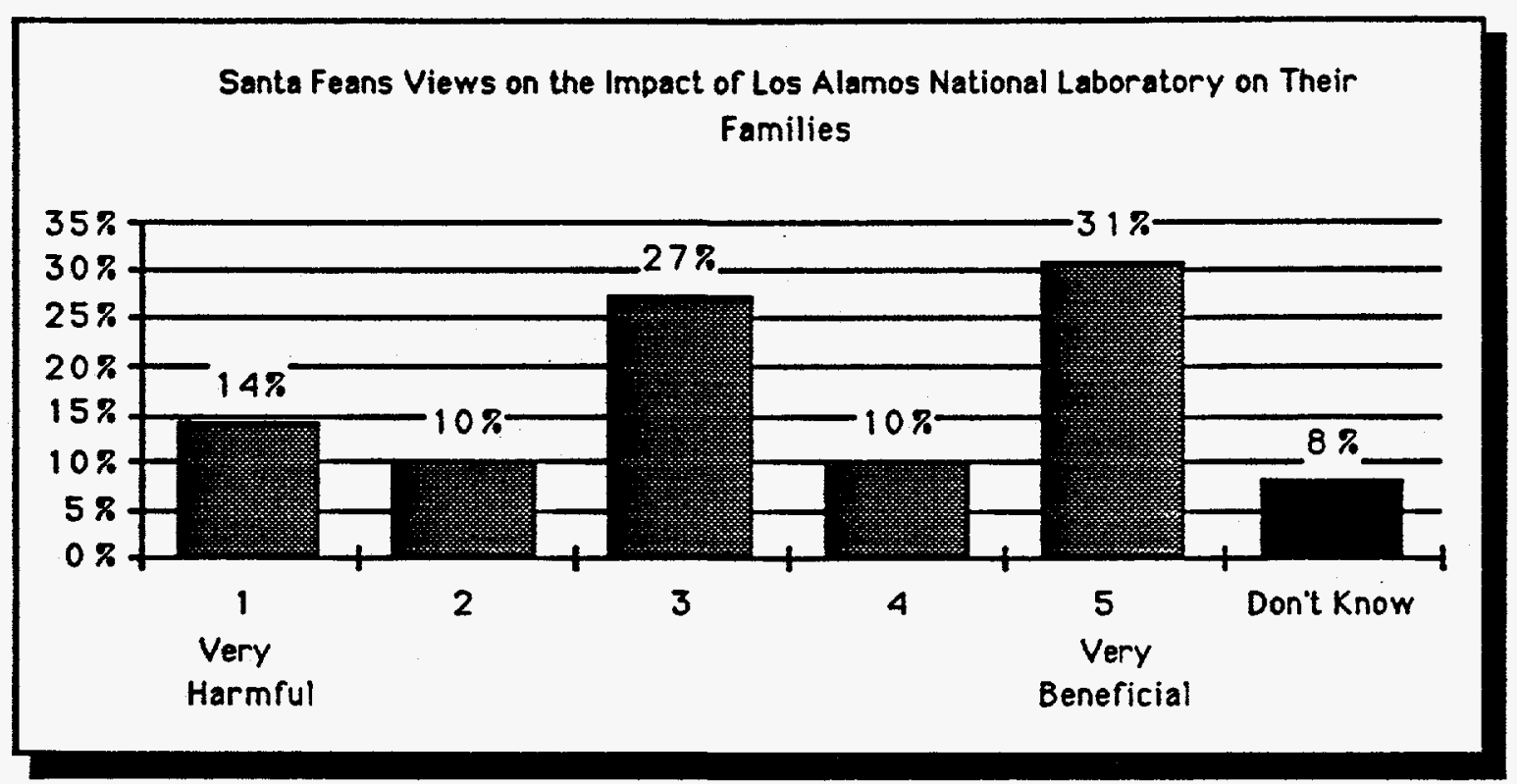

TRUST OF LANL SPOKESPERSONS AND OTHER OFFICIALS

Respondents were asked to indicate how much trust they have in various officials. Tables Three through Seven provide the complete percentage breakdown for each official. The scale used was a ten-point scale, with one indicating "not at all trustworthy" and 10 indicating "completely trustworthy." 


\section{Iable Three}

LANL Spokesperson

DOE Sookesperson

Reoion

New Mexico

SCR

Los Alamos

Santa Fe

Taos

Rio Arriba

San Miguel

Sandoval

Mora
Mean Value

6.2

6.4

$7.1 *$

5.7

$5.4^{* *}$

5.9

6.3

6.3

$7.4 * *$
Begion

New Mexico

SCR

Los Alamos

Santa Fe

Taos

Rio Arriba

San Miguel

Sandoval

Mora

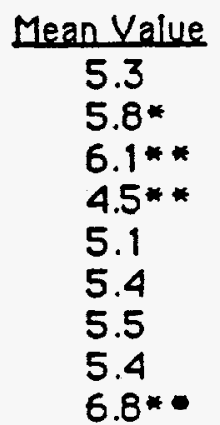

* Mean value is statistically different from that of entire state

* Mean value is statistically different from that of the rest of New Mexico

Table Three shows that Mora County residents, on average, gave a LANL spokesperson a higher trust rating than did residents of any other county. Los Alamos County residents also gave a LANL spokesperson a significantly higher rating, at 7.1. Taos County residents indicated the lowest level of trust in a LANL spokesperson, with a 5.4 on the ten-point scale. This difference also is significantly lower than the trust level of New Mexicans in general.

Mora and Los Alamos County residents also place significantly more trust in a U.S. Department of Energy spokesperson than do residents of New Mexico in general. Santa Fe County residents are the least trusting of DOE spokespersons, with a mean value of 4.5 . 


\section{Iable Four}

Research Scientist

Beaion

New Mexico

SCR

Los Alamos

Santa Fe

Taos

Rio Arriba

San Miguel

Sandoval

Mora

\begin{tabular}{l} 
Mean Value \\
\hline 6.9 \\
$7.2^{*}$ \\
$7.9^{*}$ \\
7.1 \\
6.8 \\
7.2 \\
6.7 \\
6.9 \\
$7.9^{*}$
\end{tabular}

Chemical Comoany Spokesoerson

$\begin{array}{lc}\text { Reaion } & \text { Mean Value } \\ \text { New Mexico } & 3.8 \\ \text { SCR } & 4.3^{*} \\ \text { Los Alamos } & 4.6^{*} \\ \text { Santa Fe } & 3.4 \\ \text { Taos } & 3.5 \\ \text { Rio Arriba } & 4.1 \\ \text { San Miguel } & 4.1 \\ \text { Sandoval } & 4.2 \\ \text { Mora } & 5.1^{* *}\end{array}$

- Mean value is statistically different from that of entire state

* Mean value is statistically different from that of the rest of New Mexico

Research scientists generally received the highest trust rating from our respondents, with an average for New Mexico of 6.9 on the ten-point scale and a 7.2 for the SCR. This difference is statistically significant. Los Alamos and Mora County residents again are the most trusting of these officials, each giving research scientists a 7.9 average rating.

In contrast, a chemical company spokesperson received one of the lowest trust ratings of any of the officials we asked respondents to rate. New Mexico respondents gave chemical company spokespersons a 3.8 rating, while SCR respondents were significantly higher at 4.3 . Again, Los Alamos (4.6) and Mora (5.1) residents gave chemical company spokespersons the highest ratings. 


\section{Iable Five}

Environmental Group Sookesperson

Reaion

New Mexico

SCR

Los Alamos

Santa Fe

Tros

Rio Arriba

San Miguel

Sandoval

Mora
Mean Value

5.9

6.0

5.7

6.5

6.0

6.1

6.2

5.7

$6.8 * *$
EPA Sookesperson

Region

New Mexico

SCR

Los Alamos

Santa Fe

Taos

Rio Arriba

San Miguel

Sandoval

Mora
Mean Value

5.9

6.2

6.1

6.2

6.0

6.4

6.2

5.3

$6.9 *$ *

- Mean value is statistically different from that of entire state

* Mean value is statistically different from that of the rest of New Mexico

Mora County residents also were the most trusting of an environmental group spokesperson and of the Environmental Protection Agency, with mean values of 6.8 and 6.9 respectively. All other responses were significantly lower, generally clustered around 6.0 .

\section{Iable Six}

\section{AReporter}

Reoino

New Mexico

SCR

Los Alamos

Santa Fe

Taos

Rio Arriba

San Miguel

Sandoval

Mora

\begin{tabular}{c} 
Mean Value \\
\hline 4.7 \\
4.7 \\
4.7 \\
$5.4^{* *}$ \\
4.6 \\
4.3 \\
5.2 \\
4.5 \\
5.0
\end{tabular}

\section{Savinos and Loan Sookesperson}

Reaion

New Mexico

SCR

Mean Value

3.7

3.7

Los Alamos $\quad 3.5$

Santa Fe $\quad 4.3$

Taos $\quad 3.2$

Rio Arriba $\quad 4.0$

San Miguel $\quad 4.2$

Sandoval $\quad 3.7$

Mora 3.9

- Mean value is statistically different from that of entire state

* Mean value is statistically different from that of the rest of New Mexico

Reporters and a savings and loan spokesperson received very low trust ratings from our respondents, with a savings and loan representative receiving the worst rating of any individual 
group spokesperson in our survey. New Mexico and SCR respondents gave savings and loan representatives a 3.7 average rating. The highest rating received by these spokespersons was a 4.3 from Santa Fe County residents.

Reporters faired only slightly better, with an average of 4.7 from New Mexicans and SCR residents. Santa Fe County residents also gave reporters the highest rating, at 5.4. Note that this difference is significantly different from the ratings given by the rest of New Mexico.

Iable Seyen

Nuclear Power Industry Sookesoerson

$\begin{array}{lc}\text { Reoion } & \text { MeanValue } \\ \text { New Mexico } & 4.7 \\ \text { SCR } & 4.9 \\ \text { Los Alamos } & 5.5^{*} \\ \text { Santa Fe } & 4.3 \\ \text { Taos } & 4.2 \\ \text { Rio Arriba } & 5.1 \\ \text { San Miguel } & 4.8 \\ \text { Sandoval } & 4.5 \\ \text { Mora } & 5.2\end{array}$

- Mean value is statistically different from that of entire state

* * Mean value is statistically different from that of the rest of New Mexico

Los Alamos County residents gave nuclear power industry spokespersons the highest rating among the New Mexico regions, with a mean value of 5.5 on the ten-point scale. This was significantly higher than the 4.7 given by New Mexicans in general.

As the above tables indicate, Mora County residents are significantly more trusting of officials than are residents of the rest of the state. Also, residents of the SCR, in general, tend to trust these same officials more than do residents of the entire state. 
RESPONDENT'S PRIORITIES FOR THE LABORATORY'S RESEARCH EFFORTS

Respondents were asked whether efforts in several research areas should be greatly increased, slightly increased, slightly decreased or greatly decreased. Tables Eight through Eleven provide complete percentages for each research area.

\section{Iable Ejaht}

Efforts on Pure Science and Research

\begin{tabular}{|c|c|c|c|c|c|}
\hline Region & $\begin{array}{l}\text { Greatly } \\
\text { Increase }\end{array}$ & $\begin{array}{l}\text { Slightly } \\
\text { Increase }\end{array}$ & $\begin{array}{l}\text { Slightly } \\
\text { Decrease }\end{array}$ & $\begin{array}{l}\text { Greatly } \\
\text { Decrease }\end{array}$ & Don't Know \\
\hline New Mexico & $30 \%$ & $48 \%$ & $6 \%$ & $11 \%$ & $5 \%$ \\
\hline SCR* & $32 \%$ & $53 \%$ & $5 \%$ & $8 \%$ & $2 \%$ \\
\hline Los Alamos & $33 \%$ & $51 \%$ & $14 \%$ & $0 \%$ & $2 \%$ \\
\hline Santa $\mathrm{Fe}$ & $35 \%$ & $50 \%$ & $4 \%$ & $6 \%$ & $4 \%$ \\
\hline Taos & $35 \%$ & $47 \%$ & $2 \%$ & $12 \%$ & $4 \%$ \\
\hline Rio Arriba & $41 \%$ & $52 \%$ & $0 \%$ & $7 \%$ & $0 \%$ \\
\hline San Miguel & $29 \%$ & $61 \%$ & $5 \%$ & $5 \%$ & $0 \%$ \\
\hline Sandoval & $22 \%$ & $59 \%$ & $2 \%$ & $11 \%$ & $7 \%$ \\
\hline Mora & $38 \%$ & $46 \%$ & $4 \%$ & $13 \%$ & $0 \%$ \\
\hline
\end{tabular}

* SCR responses are significantly different from those of residents of the entire state using an analysis of variance statistical technique

Respondents generally were in favor of increasing research efforts on pure science/ research, with 78 percent of New Mexicans saying these efforts should be greatly or slightly increased. SCR residents were significantly more in favor of increasing such efforts, at 85 percent. 
Iable Nine

Efforts on Environmental Research

\begin{tabular}{|c|c|c|c|c|c|}
\hline Region & $\begin{array}{l}\text { Greatly } \\
\text { Increase }\end{array}$ & $\begin{array}{l}\text { Slightly } \\
\text { Increase }\end{array}$ & $\begin{array}{l}\text { Slightly } \\
\text { Decrease }\end{array}$ & $\begin{array}{l}\text { Greatly } \\
\text { Decrease }\end{array}$ & Don't Know \\
\hline New Mexico & $62 \%$ & $30 \%$ & $3 \%$ & $6 \%$ & $2 \%$ \\
\hline SCR & $61 \%$ & $29 \%$ & $5 \%$ & 47 & $2 \%$ \\
\hline Los Alamos & $61 \%$ & $28 \%$ & $11 \%$ & $0 \%$ & $0 \%$ \\
\hline Santa Fe & $71 \%$ & $24 \%$ & $2 \%$ & $0 \%$ & $4 \%$ \\
\hline Taos & $66 \%$ & $24 \%$ & $0 \%$ & $9 \%$ & $2 \%$ \\
\hline Rio Arriba & $74 \%$ & $24 \%$ & $2 \pi$ & $0 \%$ & $0 \%$ \\
\hline San Miguel & $59 \%$ & $29 \%$ & $3 \%$ & $7 \%$ & $2 \%$ \\
\hline Sandoval & $51 \%$ & $30 \%$ & $6 \%$ & $6 \%$ & $6 \%$ \\
\hline Mora & $58 \%$ & $35 \%$ & $4 \%$ & $0 \%$ & $2 \%$ \\
\hline
\end{tabular}

The overwhelming majority --some 92 percent of the state's respondents-- said efforts on environmental research should be greatly or slightly increased, while 90 percent of SCR residents said the same. More Rio Arriba County residents, 98 percent, said these efforts should be increased than did residents of any other region.

\section{Iable Ten}

Efforts on Defense and Weapons Development

\begin{tabular}{|c|c|c|c|c|c|}
\hline Region & $\begin{array}{l}\text { Greatly } \\
\text { Increase }\end{array}$ & $\begin{array}{l}\text { Slightly } \\
\text { Increase }\end{array}$ & $\begin{array}{l}\text { Slightly } \\
\text { Decrease }\end{array}$ & $\begin{array}{l}\text { Greatly } \\
\text { Decrease }\end{array}$ & Den't Know \\
\hline New Mexico & $20 \%$ & $31 \%$ & $9 \%$ & $26 \%$ & $14 \%$ \\
\hline SCR & $16 \%$ & $27 \%$ & $13 \%$ & $30 \%$ & $14 \%$ \\
\hline Los Alamos & $10 \%$ & $23 \%$ & $23 \%$ & $35 \%$ & $8 \%$ \\
\hline Santa Fe & $16 \%$ & $24 \%$ & $10 \%$ & $24 \%$ & $27 \%$ \\
\hline Taos & $14 \%$ & $24 \%$ & $10 \%$ & $31 \%$ & $21 \%$ \\
\hline Rio Arriba & $25 \%$ & $28 \%$ & $4 \%$ & $23 \%$ & $19 \%$ \\
\hline San Miguel & $12 \%$ & $33 \%$ & $5 \%$ & $38 \%$ & $12 \%$ \\
\hline Sandoval & $24 \%$ & $22 \%$ & $16 \%$ & $22 \%$ & $16 \%$ \\
\hline Mora & $19 \%$ & $33 \%$ & $15 \%$ & $23 \%$ & $10 \%$ \\
\hline
\end{tabular}


New Mexicans were most evenly split on the question regarding defense and weapons development efforts. While 51 percent of New Mexicans in general said these efforts should be increased; only 43 percent of SCR residents said these efforts should be increased and 43 percent said they should be decreased.

Perhaps most surprising is that only 33 percent of Los Alamos County residents said defense and weapons development efforts should be increased and 58 percent said these efforts should be decreased. That percentage was the greatest of any individual county or of the SCR. While more Taos County residents said these efforts should be decreased than increased, this difference was not as great as in Los Alamos County.

\section{Iable Eleven}

Efforts on Technology Transfer to Industry

\begin{tabular}{|c|c|c|c|c|c|}
\hline Reoion & $\begin{array}{l}\text { Greatly } \\
\text { Increase }\end{array}$ & $\begin{array}{l}\text { Slightly } \\
\text { Increase }\end{array}$ & $\begin{array}{l}\text { Slightly } \\
\text { Decrease }\end{array}$ & $\begin{array}{l}\text { Greatly } \\
\text { Decrease }\end{array}$ & Don't Know \\
\hline New Mexico & $42 \%$ & $45 \%$ & $3 \%$ & $8 \%$ & $1 \%$ \\
\hline SCR* & $34 \%$ & $43 \%$ & $8 \%$ & $11 \%$ & $4 \%$ \\
\hline Los Alamos & $37 \%$ & $46 \%$ & $12 \%$ & $3 \%$ & $2 \%$ \\
\hline Santa Fe & $39 \%$ & $51 \%$ & $4 \%$ & $2 \%$ & $4 \%$ \\
\hline Taos & $28 \%$ & $48 \%$ & $2 \%$ & $16 \%$ & $7 \%$ \\
\hline Rio Arriba & $54 \%$ & $27 \%$ & $6 \%$ & $10 \%$ & $2 \%$ \\
\hline San Miguel & $18 \%$ & $55 \%$ & $4 \%$ & $18 \%$ & $6 \%$ \\
\hline Sandoval & $37 \%$ & $35 \%$ & $11 \%$ & $13 \%$ & $4 \%$ \\
\hline Mora & $42 \%$ & $38 \%$ & $13 \%$ & $7 \%$ & $0 \%$ \\
\hline
\end{tabular}

" SCR responses are significantly different from those of residents of the entire state using an analysis of variance technique

Respondents generally were in favor of increasing efforts in technology transfer to industry, although SCR residents were less in favor of increasing these efforts than were New Mexicans in general. Sandoval and San Miguel County residents were the least in favor of increasing these efforts at 72 and 73 percent respectively. 


\section{RESPONDENT'S VIEW ON SCIENCE AND TECHNOLOGY}

Residents also were asked to indicate whether they agree with several statements about science and technology issues. These questions are: $Q .14$ - Science tells us the truth about the world. Q.15 - Science can be interpreted to fit any point of view. Q.16 - Technology can solve society's problems. Q.17 - Technology has become dangerous and unmanageable. $Q .18$ - Science can only be understood by scientists. Table 12 provides the percentage breakdown for each question for the entire state.

Iable 12

Questions on Science and Technology

$\begin{array}{lccccc} & & \text { Aaree Stronaly } & \text { Aoree } & \text { Disaoree } & \text { Disaoree Stronaly } \\ \text { Tell Truth } & (Q 14) & 12.0 \% & 57.9 \% & 24.4 \% & 5.7 \% \\ \text { Sci Interpret } & (Q 15) & 14.2 \% & 58.9 \% & 25.7 \% & 1.2 \% \\ \text { Tech Solve } & (Q 16) & 6.7 \% & 38.3 \% & 46.8 \% & 8.3 \% \\ \text { Tech Danger } & (Q 17) & 4.7 \% & 29.0 \% & 60.3 \% & 6.1 \% \\ \text { Understd Sci } & (Q 18) & 1.8 \% & 13.0 \% & 71.5 \% & 13.9 \%\end{array}$

For complete survey questions, including those concerning science and technology issues, please refer to Appendix B. The exact question wording and the response categories used in this survey are provided in the appendix. 


\begin{tabular}{|c|c|c|c|}
\hline \multicolumn{4}{|c|}{ APPENDIX A } \\
\hline \multicolumn{4}{|c|}{ REGRESSION TABLES } \\
\hline \multicolumn{4}{|c|}{ Table 13} \\
\hline \multicolumn{4}{|c|}{ Explaining Respondent's Overall View of LANL } \\
\hline & $2=.07$ & & \\
\hline Intercept: & & & \\
\hline Independent Variable: & Coeff: & Std Coeff: & Probability \\
\hline Trust-LANL & .071 & .174 & .0003 \\
\hline Science Interpreted & .152 & .11 & .0147 \\
\hline Proud-LANL & -.109 & -.096 & .0449 \\
\hline Read LANL Paper & -.251 & -.138 & .0024 \\
\hline
\end{tabular}

Table 14

Explaining Respondent's Overall View of LANL for the Surrounding Counties

$$
\left(R^{2}=.15\right)
$$

Intercept: 4

Independent Variable:

Coeff:

Std. Coeff: Probability

Male

.19

.11

.05

Proud-LANL

$-.39$

$-.36$

.0001

Read LANL Paper

$-.2$

$-.12$

.0322 
Table 15

Explaining Respondent's View of LANL's Environmental Responsibility $\left(R^{2}=.314\right)$

$\begin{array}{lccc}\text { Intercept: } & 1.374 & & \\ & & & \\ \text { Independent Variable: } & \text { Coeff: } & \text { Std. Coeff: } & \text { Probability } \\ \text { Trust-LANL } & .227 & .492 & .0001 \\ \text { Tech Dangerous } .2 & .119 & .0003 & \\ \text { Ideology } & .082 & .109 & .0009 \\ \text { Male } & -.159 & -.073 & .0243\end{array}$

Table 15.1

Explaining Respondent's View of LANL's Environmental Responsibility Demographic Variables Only

$$
\left(R^{2}=.047\right)
$$

Intercept: $\quad 3.33$

$\begin{array}{lccc}\text { Independent Variable: } & \text { Coeff: } & \text { Std. Coeff: } & \text { Probability } \\ \text { Ideology } & .137 & .189 & .0001 \\ \text { Education } & -.071 & -.099 & .0392\end{array}$

Table 16

Explaining Respondent's View of LANL's Environmental Responsibility for the Surrounding Counties

$$
\left(R^{2}=.073\right)
$$

Intercept: $\quad 5.23$

$\begin{array}{llcc}\text { Independent Variable: } & \text { Coeff: } & \text { Std Coeff: } & \text { Probability } \\ \text { Science Tells Truth } & -.36 & -.204 & .0005 \\ \text { Understand Science } & -.276 & -.124 & .0383 \\ \text { Years in NM } & .008 & .12 & .0454\end{array}$


Table 17

Explaining Respondent's View of LANL's Effect on National Defense $\left(R^{2}=.062\right)$

Intercept: $\quad 4.545$

Independent Variable:

Coeff:

Std. Coeff: Probability

Ideology

.119

.165

.0002

Technology Solve

$-.258$

$-.181$

.0001

Table 18

Explaining Respondent's Pride in having the Laboratory in New Mexico $\left(R^{2}=.133\right)$

intercept: $\quad 2.648$

Independent Variable:

Coeff:

Std Coeff: Probability

Trust-LANL

$-.104$

$-.3$

.0001

Years in New Mexico

$-.007$

$-.167$

.0001

See LANL in Television

$-.187$

$-.115$

.0078 


\section{APPENDIX B}

\section{SURVEY INSTRUMENT}

Hello, my name is and I am

calling from the University

of New Mexico. We are conducting a statewide survey of New Mexico

residents who are 18 years of age or older. This is a random survey and your number was selected by a computerized random number generator.

However, to insure the randomness of this survey, I would like to speak to

the person who is at home right now who has had the most recent birthday.

The University of New Mexico is conducting a survey of New Mexico residents

regarding their opinions and perceptions of Los Alamos National Laboratory.

The University does not release information concerning how any one person

answers these questions, so your answers will be STRICTLY confidential.

If you have a few minutes, I would like to ask you some questions...

1. We're interested in what areas of research you think Los Alamos National

Laboratory scientists are involved. Could you plesse tell me what kind of research the Laboratory does?

Institute for Public Policy
2. Is there anything else?

[DO NOT READ RESPONSES]

1. pure sci/research

2. medical research

3 . environ. research

4. defense/weapons

5 . tech. transfer

6 . other

7. DK/NA

IINTERVIEWER--PLEASE DESCRIBE AND BE SPECIFIC PLEASE]

1. pure sci/research

2 . medical research

3. environ. research

4. defense/weapons

5 . tech. transfer

6 . other

7. DK/NA

IINTERVIEWER, PLEASE DESCRIBE OTHER---BE SPECIFIC] 
3. We're interested in your view of Los Alamos National Laboratory. In

general, what do you think of the Laboratory?

Are your views very

unfavorable, somewhat unfavorable, somewhat

favorable or very favorable?

1. very unfavorable

2. somewhat unfavorable

3 . somewhat favorable

4. very favorable

5. DK/NA

4. Now thinking about environmental issues, how environmentally

responsible would you say Los Alamos National Laboratory has been?

On scale of one to five where 1 is very irresponsible and $\mathbf{5}$ is very

responsible, where would you place Los Alamos National Laboratory?

1. I very irresponsible

2. 2

3.3

4. 4

5 . 5 very responsible

6. DK/NA

Using a scale of one to five where 1 is very harmful and 5 is very beneficial, where would you place Los Alamos National Laboratory on the following issues:
5. The impact of the Laboratory on the economy of the entire state.

1. I very harmful

2. 2

$3 \cdot 3$

4. 4

5 . 5 very beneficial

6. DK/NA
6. The effect of the Laboratory in national defense.

1. I very harmful

2. 2

3.3

4. 4

5. 5 very beneficial

6. DK/NA

7. The impact of Los Alamos Laboratory on you and your family.

1. I very harmful

2. 2

$3 \cdot 3$

4. 4

5. 5 very beneficial

6. DK/NA 
8. How important do you think Los Alamos National Laboratory is in overall

scientific research. On a scale of one to five where 1 is not at all important

and 5 is very important, where would you place the laboratory?

1. I not at all important

2. 2

3.3

4.4

5. 5 very important

6. DK/NA

Please tell me whether you agree strongly, sgree, disagree or disagree

strongly with the following statement:

9. Overall, Los Alamos National Laboratory is something that the state of

New Mexico can be proud of.

1. agree strongly

2. agree

3 . disagree

4. disagree strongly

5. DK/NA

10. Do you or does anyone you know currently work for Los Alamos National Laboratory?

1. Yes

2. No

3. DK/NA 10a.) Given what you know about the Laboratory, would you rate it as an excellent, good, fair or poor place to work?

1. Excellent

2. Good

3. Fair

4. Poor

5. DK/NA

11. How many days a week do you watch network television news?

1 . never

2. I day weekly

3. 2 days weekly

4. 3 days weekly

5. 4 days weekly

6. 5 days weekly

7. 6 days weekly

8. 7 days weekly

9. DK/NA

12. In the last six months, have you seen any network television news stories that mentioned the laboratory?

1. Yes

2. No

3. DK/NA 
12a) In your view did the story portray the Laboratory in a positive,

negative or neutral light?

1. Positive

2. Negative

3. Neutral

4. DK/NA

13. In the last six months, have you seen any television news stories on

science and technology?

1. Yes

2. No

3. DK/NA

13a) In your view, was science and technology overall portrayed in a

positive, negative or neutral light?

1. Positive

2. Negative

3. Neutral

4. DK/NA

11. How many days a week do you read a newspaper?

1 . never

2. 1 day weekly

3. 2 days weekly
4. 3 days weekly

5 . 4 days weekly

6. 5 days weekly

7. 6 days weekly

8. 7 days weekly

9. DK/NA

12. In the last six months, have you read any newspaper articles that mentioned the laboratory?

1. Yes

2. No

3. DK/NA

12a) In your view did the story portray the Laboratory in a positive. negative or neutral light?
1. Positive
2. Negative
3 . Neutral
4. DK/NA

13. In the last six months, have you read any newspaper articles on science and technology?
1. Yes
2. No
3. DK/NA 
13a) In your view, was science and technology overall portrayed in a

positive, negative or neutral light?

1. Positive

2. Negative

3. Neutral

4. DK/NA

Please indicate whether you agree strongly, agree, disagree or disagree

strongly with the following statements:

14. Science tells us the truth about the world.
1. agree strongly
2. agree
3 . disagree
4. disagree strongly
5. DK/NA

1. agree strongly

2. sgree

3 . disagree

4. disagree strongly

5. DK/NA

17. Technology has become dangerous and unmanageable.
1. agree strongly
2. agree
3 . disagree
4. disagree strongly
5. DK/NA

18. Science can only be understood by scientists.
1. ogree strongly
2. agree
3 . disagree
4. disagree strongly
5. DK/NA

15. Scientific evidence can be interpreted to fit any point of view.
1. agree strongly
2 . agree
3 . disagree
4. disagree strongly
5. DK/NA

19. Now I'm going to read you a list of research areas in which Los Alamos

National Laboratory is involved. Please indicate whether the efforts in these areas should be greatly increased, slightly increased, slightly decreased or greatly decreased.

16. Technology can solve society's problems. 


\section{$e^{n-\cdots}$}

19a) Basic scientific exploration into the fundamental processes of nature.

[DO NOT READ RESPONSE 'ABOUT THE SAME']

1. greatly increase

2 . slightly increase

3. about the same

4. slightly decrease

5 . greatly decrease

6. DK/NA

19b) Environmental research issues.

[DO NOT READ RESPONSE 'ABOUT THE SAME']

1. greatly increase

2 . slightly increase

3. about the same

4. slightly decrease

5 . greatly decrease

6. DK/NA

19c)Defense and weapons development.

[DO NOT READ OPTION 'ABOUT THE SAME']

1. greatly increase

2 . slightly increase

3. about the same

4. slightly decrease

5. greatly decrease

\section{DK/NA}

19d) Technology transfer to Industry.

IDO NOT READ RESPONSE 'ABOUT THE SAME' ]
1. greatly increase
2. slightly increase
3 . about the same
4. slightly decrease
5. greatly decrease
6. DK/NA

On a scale of 1 to 10 where 1 is not at all trustworthy and 10 is completely trustworthy. we would like to know how much trust you would

place in the following officials.

24. A spokesperson for the U.S. Department of Energy.

1. I not at all trustworthy

2. 2

3.3

4. 4

5.5

6.6

7.7

8. 8

9. 9

10. 10 completely trustworthy

11 . DK/NA 
25. A spokesperson for a chemical company.

1. I not at all trustworthy

2. 2

3. 3

4. 4

5.5

6. 6

7. 7

8. 8

9.9

10. 10 completely trustworthy

11 . DK/NA

26. A spokesperson for an environmental group.

1. I not at all trustworthy

2. 2

$3 \cdot 3$

4. 4

5.5

6. 6

7.7

8. 8

9.9

10. 10 completely trustworthy

11. DK/NA
3.3

4. 4

5.5

6. 6

7.7

8. 8

9.9

10. 10 completely trustworthy

11. DK/NA

23. A spokesperson for Los Alamos National Laboratory.

1. I not at all trustworthy

2. 2

3.3

4. 4

5. 5

6. 6

7. 7

8. 8

9. 9

10. 10 completely trustworthy

11. DK/NA

28. A spokesperson for the nuclear power industry.

1. I not at all trustworthy

2. 2

Institute for Public Policy 
29. A research scientist.

1. 1 not at all trustworthy

2. 2

3.3

4.4

5.5

6.6

7.7

8. 8

9.9

10. 10 compietely trustworthy

11. DK/NA

30. A spokesperson for the U.S. Environmental

Protection Agency.

1. 1 not at all trustworthy

2. 2

3. 3

4. 4

5.5

6.6

7.7

8. 8

9. 9

10. 10 completely trustworthy

11. DK/NA
4. 4

5.5

6. 6

7.7

8. 8

9.9

10. 10 completely trustworthy

11. DK/NA

32. A spokesperson for a savings and loan organization.

1. I not at all trustworthy

2. 2

3.3

4. 4

5. 5

6. 6

7.7

8. 8

9. 9

10. 10 completely trustworthy

11. DK/NA

31. A reporter.

1. I not at all trustworthy

2. 2

$3 \cdot 3$

Institute for Public Policy 


\section{What county do you live in?}

What kind of impact does the Laboratory have on the economies of the communities surrounding it? Using scale of one to five where one is very

harmful and five is very beneficial, where would you place Los Alamos

National Laboratory on this issue?

1. 1-very harmful

2. $2-$

3 . 3-

4. 4-

5. 5-very beneficial

6. DK/NA
1. Rio Arriba

2. Sandoval

3 . Sante $\mathrm{Fe}$

4. Taos

5 . Mora

6. San Miquel

7. Los Alamos

B. other

[INDICATE THE RESPONDENT'S COUNTY]

34. What is your current occupation?

32b. Would you agree strongly, agree, disagree, or disagree strongly with

the following statement: Northern New Mexico's communities are too

1. exec/admin/manag

dependent on the Laboratory's contribution to the local economy.

2 . prof. specialties

3 . tech/sales/ad. suppo

4. service

5. agric/forest/fish

6. production/craft/rep

1. agree strongly

7 . oper/fab/laborers

2. agree

8. student

3 . disagree

9. homemakers

4. disagree strongly

10. ret./unemployed

Finally, we need some background information about you. 
35. How much education have you had?

1. 1-K-8th grade

2. 2-some high school

3. 3-high school grad

4. 4-post HS trade scho

5. 5-some college

6. 6-college grad

7. 7-grad work

8. 8-NR/DK

36. How old were you on your last birthday?

lowscale $=18$ highscale $=120$

37. What is your race or ethnic background? Are you:

[READ RESPONSES]

1. 1-white

2. 2-African-Amer.

3. 3-Spanish-Amer.

4. 4-Mexican-Amer.

5. 5-Asian

6. 6-American Indian

7. 7-Other

8. 8-refused (DK/NR)
38. Individuals can be arranged on a scale of ideology running from 1.

being extremely liberal, to 7, being extremely conservative. On that 7 point scale, where would you place yourself?

1. 1-extremely liberal

2. 2-liberal

3. 3-slightly liberal

4. 4-moderate

5. 5-slightly conserv.

6. 6-conservative

7. 7-extremely conserv.

8. 8-DK/NR

39. Was your total family income for the past year less than $10.000 ; 10$ to 20,$000 ; 20$ to 30,$000 ; 30$ to 40,$000 ; 40$ to 50,000 ; or more than 50,000 ?
1. 1-under 10K

2. $2-10 K-20 K$

3. 3-20K-30K

4. $4-30 K-40 K$

5. $5-40 K-50 K$

6. 6-over $50 \mathrm{~K}$

7. 7-refused

8. 8-DK/NA 
40. Are you currently registered to vote?
1. Yes
2. No
3. DK/NA

41. With which political party do you identify?

1. 1-Democrat

2. 2-Independent

3. 3-Republican

4. 4-other

5. 5-DK/NR

42. How many years have you lived in New Mexico?

lowscale $=1$ highscale $=120$

43. What is your current zip code?

IENTER ONLY THE LAST 4 DIGITS OF THE RESPONDENT'S ZIP CODE--ALL NEW

MEXICO ZIP CODES BEGIN WITH '8']

lowscale $=0$ highscale $=9999$
Thank you very much for taking the time to talk with me today. One final thing, could I have your first name in case my supervisor needs to call back

to verify that I have actually spoken to you?

IIF THE RESPONDENT IS RELUCTANT TO GIVE FIRST NAME, ASK FOR A NICKNAME OR AN INITIAL INSTEAD]

Record the respondent's gender:
1. Male

2. Female 